\title{
DANKBARE HULDE
}

Hierdie uitgawe van "Koers" is 'n beskeie maar egte blyk van wardering aan twee akademiese pioniers aan die Potchefstroomse Universiteit vir C.H.O.: nl. professore D. J. van Rooy en A. P. Goossens, wat albei reeds die diensjaargrens bereik het, maar nog as emeritus-professore werksaam is. Hoeveel die Universiteit aan hulle arbeid vir sy ontwikkeling verskuldig is, sal nie maklik bepaal kan word nie; daarvoor is die aandeel te groot en oorspan dit te veel terreine. Die feit dat die vier artikels in hierdie uitgawe geskryf is deur oudstudente wat almal die status van professor beklee sprcek vanself. Albei het diep spore getrap, reuse-spore.

Na die emeritaat kom daar ook geen verposing nie: sowel prof. Van Rooy as prof. Goossens is nog honderd persent aktief, dien op openbare, akademiese en regerings-liggame en kommissies van deurslaggewende belang, is nog voltyds besi. met doseerwerk aan die Universiteit, en, om die kroon te span, verskyn daar nog steeds publikasies uit hulle hand.

Onder hulle kollegas en tydgenote was (en is) hulle veelgesogte leiers; vir die jonger akademiese geslag het hulle 'n hoë standaard gestel en bly hulle 'n voortstuwende of lonkende inspirasie; vir die Potchefstroomse Universiteit vir C.H.O. is hulle 'n sieraad en uitbouers van' $n$ trotse tradisie op hulle vakgebied, maar bo alles is hulle grondleggers van 'n Christelike Wetenskap.

Die Direksie, Redaksie en lede van „Koers” kan natuurlik ook nooit vergeet dat prof. D. J. van Rooy 'n stigterslid van hierdie blad is en op die eerste redaksie daarvan gedien het nie. Sedertdien was hy altyd wyse raadgewer en in moeilike tye 'n steunpilaar. Sy naam staan onuitwisbaar in die annale van "koers".

W. N. Coetzee 
